JOURNAL OF ETHNOBIOLOGY

AND ETHNOMEDICINE

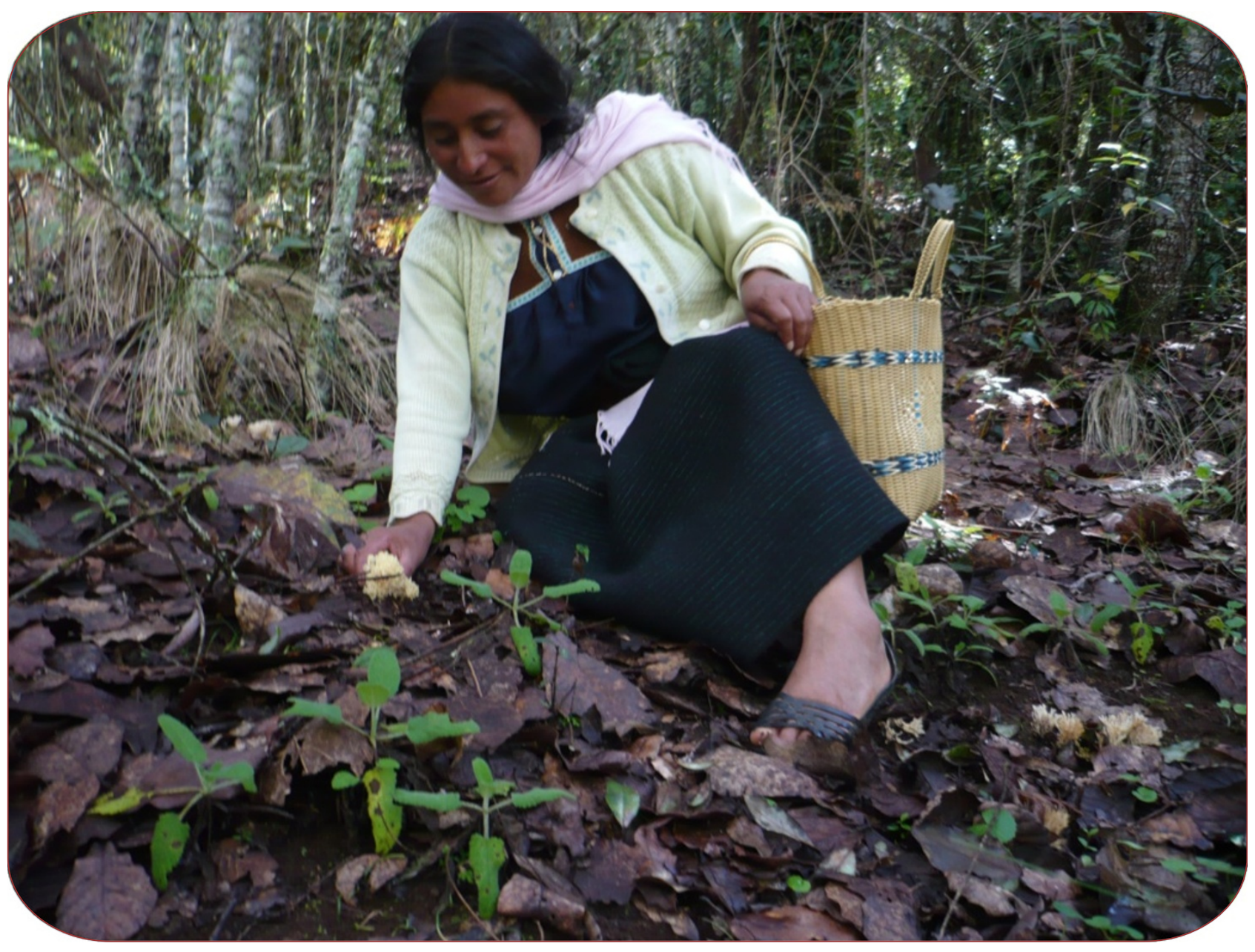

\title{
Women care about local knowledge, experiences from ethnomycology
}

Garibay-Orijel et al. 


\title{
Women care about local knowledge, experiences from ethnomycology
}

\author{
Roberto Garibay-Orijel ${ }^{1 *}$, Amaranta Ramírez-Terrazo ${ }^{2}$ and Marisa Ordaz-Velázquez ${ }^{3}$
}

\begin{abstract}
Gender is one of the main variables that influence the distribution of local knowledge. We carried out a literature review concerning local mycological knowledge, paying special attention to data concerning women's knowledge and comparative gender data. We found that unique features of local mycological knowledge allow people to successfully manage mushrooms. Women are involved in every stage of mushroom utilization from collection to processing and marketing. Local mycological knowledge includes the use mushrooms as food, medicine, and recreational objects as well as an aid to seasonal household economies. In many regions of the world, women are often the main mushroom collectors and possess a vast knowledge about mushroom taxonomy, biology, and ecology. Local experts play a vital role in the transmission of local mycological knowledge. Women participate in the diffusion of this knowledge as well as in its enrichment through innovation. Female mushroom collectors appreciate their mycological knowledge and pursue strategies and organization to reproduce it in their communities. Women mushroom gatherers are conscious of their knowledge, value its contribution in their subsistence systems, and proudly incorporate it in their cultural identity.
\end{abstract}

Keywords: Ethnomycology, Gendered local knowledge, Women, Mushroomers, Mushrooms, Use, and Management

\section{Resumen}

El género es una de las principales variables que afectan la distribución de los saberes locales. Nosotros realizamos una revisión bibliográfica sobre el conocimiento micológico tradicional, prestando especial atención a los datos sobre conocimiento local de mujeres y datos comparativos entre géneros. Encontramos que el conocimiento micológico tradicional tiene características únicas que le permiten a la gente hacer un manejo adecuado de los hongos silvestres. Las mujeres se encuentran involucradas en todas las fases del uso de los hongos; desde la recolección y el procesamiento, hasta la comercialización. El conocimiento micológico tradicional incluye el uso de hongos como comida, medicina y objetos recreativos, así como un soporte de la economía familiar. En muchas regiones del mundo, las mujeres son generalmente las principales recolectoras de hongos y poseen un vasto conocimiento sobre la taxonomía

\footnotetext{
* Correspondence: rgaribay@ibunam2.ibiologia.unam.mx

'Laboratorio de Sistemática, Ecología y Aprovechamiento de Hongos

Ectomicorrízicos, Departamento de Botánica, Instituto de Biología,

Universidad Nacional Autónoma de México, Circuito Exterior s/n, A.P. 70-233,

C.P. 04510, Ciudad Universitaria, D.F, Mexico

Full list of author information is available at the end of the article
}

local, biología y ecología de estos organismos. Los expertos locales juegan un rol vital en la transmisión del conocimiento micológico tradicional. Las mujeres, en particular, participan tanto en la difusión de estos conocimientos, como en su enriquecimiento a través de la innovación. Las recolectoras de hongos aprecian su conocimiento y buscan estrategias y organización para reproducirlo en sus comunidades. Las hongueras están consientes de su conocimiento, valoran la contribución que éste hace a su sistema de subsistencia y lo incorporan con orgullo a su identidad cultural.

Palabras clave: Etnomicología, conocimiento local con perspectiva de género, mujeres, hongueras, hongos, uso y aprovechamiento.

\section{Review}

Gender is one of the main variables that influence local knowledge distribution [1]. It acts at two levels. The first is a consequence of culturally assigned roles for men and women and is known as "gendered knowledge". Obvious examples include childcare and cooking. The second is derived from division of labor as a result of biological differences between men and women. Even 
while both engage in major activities, gender stratification occurs often linked to specific techniques or species than to participation itself [2]. However, most ethnobiological studies do not include gender comparisons. Reviews indicate that this lack of gender consciousness results in three kinds of errors: biased research design which causes omission; imbalanced analysis resulting in erroneous interpretation; and unreliability of sources which can lead to erroneous conclusions [1,3]. However, these papers make no reference to ethnomycological knowledge. While there are hardly any gender studies in ethnomycology, many give data on gender differences (Table 1). In contrast to ethnobotanical and ethnozoological knowledge, women are typically involved in all the processes of wild edible mushroom management.

In this paper we use the gender differences in ethnomycological knowledge to demonstrate that women indeed care about it and value their role in its permanence. To accomplish this, we carried out a bibliographical review concerning local mycological knowledge, paying special attention to data concerning women's knowledge and comparative gender data. Because Mexico is the country where most ethnomycological surveys have been carried out [4], a third of the references come from that region. We complement our analysis with our own field observations. Additionally, we incorporate data derived from a participatory workshop organized by the Universidad Autonoma de Chapingo called the National Mushroom Gatherers Forum "Primer Foro Nacional de Hongueros", held in Chapingo, Mexico in August 2010. This Forum brought together regional experts on local mycological knowledge "hongueros" (mushroom collectors), researchers, and students. During the workshop, mushroom gatherers discussed their role in their communities and the challenges they face. We extracted information from women's commentaries and provide original quotes in Spanish (Additional file 1).

\section{The nature of local mycological knowledge}

Local mycological knowledge has features that distinguish it from both zoological and botanical knowledge. Most of these arise from fungal biology, ecology, and metabolism.

Traditional knowledge related to mushrooms is restricted to its fruit bodies, which represent the sexual stage of their life cycle [5]. There are few examples of the traditional use of their vegetative structures like mycelia or sclerotia [6]. As a consequence, only a small part of the fungal organism is subject to cultural recognition and use (Figure 1A). In contrast, plants and animals are more easily recognized as units as a whole, as well as composed of distinct structures with diverse uses. Because mushrooms have no organ development, they are often used entirely. Even while some parts of the fruit body could be removed because of bad flavor, there is rarely differential part use $[7,8]$. This limited structural diversity constrains the uses of mushrooms as happens with other simple organisms as non vascular plants, insects, or worms.

Mushroom production is uneven throughout the year; their appearance in temperate forests is restricted to the rain season. Consequently, the limited availability of wild mushrooms alters people behavior and fungi use during the mushroom season [9]. Given the fairly random and aggregated distribution of mushrooms, they cannot be accurately mapped from one year to the next. This differs from plant gathering, where the location of organisms is more predictable. Thus, mushroom gathering requires abilities more akin to those of hunters where greater knowledge of the habitat, niche, and morphology of useful fungi is needed in order to improve the gatherer's success [10]. For mushroom gatherers, locating a particular species becomes more challenging. However, they usually forage in fixed "paths" or forest areas.

Foraging strategies are designed to maximize the chance of finding a group of species at a given time of the year. Species with high economic value (e.g., truffles, boletes, and chantharelles) are the exception, because even a small amount of these is worth the effort and time invested in foraging [9,11-13]. Most of these species are ectomycorrhizal, so they are not currently cultivated and their fruit bodies are scarce. Most cultivated mushrooms are saprobes while some are facultative. Because they are produced in great quantities, their prices are lower [14]. Consequently, the procurement of high-value mushrooms is highly dependent on local mycological knowledge. In contrast, technical knowledge has been developed on saprobe species.

As is the case with plants, mushrooms' complex metabolism generates many byproducts. Among these are antibiotics, beta-glucanes, psychoactive compounds, and toxins [15] which confer them their medicinal, entheogenic, toxic, or even lethal properties. The most striking social effect is that a handful of toxic species generate awareness or even a subjacent fear when mushrooms are eaten. People will act cautiously and even refuse eating new edible mushrooms, while not so if faced with new plant or animal products. Even collectors avoid touching unrecognized species. Furthermore, these are usually grouped together in a residual category like toadstool among English speakers [12] and "jhasmuka" or "lu'" among some Mayan groups [16,17]. These terms are used to reinforce the cautious attitudes toward species not locally recognized as edible. A unique feature of local mycological knowledge, first characterized by Wasson, is the existence of mycophilic and mycophobic societies [18-20]. This is, entire cultures adopting 


\begin{tabular}{|c|c|c|}
\hline Ref & Place & Results \\
\hline 16 & Chiapas, Mex & Men collect in forests while women collect closest to their houses. \\
\hline 27 & Hungary & Most mushroom vendors in markets are women. \\
\hline 34 & Ozumba, Mex & $\begin{array}{l}\text { Women are the main mushroom collectors and vendors. Mothers teach children to distinguish the mushrooms in "good ones" } \\
\text { and "bad ones". }\end{array}$ \\
\hline 36 & $\begin{array}{l}\text { South } \\
\text { Cameroon }\end{array}$ & $\begin{array}{l}\text { Men collect in forests while women collect closest to their houses. Mothers encourage children to foray for mushrooms. } \\
\text { Mushrooms allow women to become economically independent, acquire essentials goods, and complement their diet. }\end{array}$ \\
\hline 38 & $\begin{array}{l}\text { Southeastern } \\
\text { Poland }\end{array}$ & Men are slightly more involved in mushroom gathering than women. Sex differences in knowledge transmission are slight. \\
\hline 39 & Southeast Asia & In most cases the women do more gathering of mushrooms than men. \\
\hline 40 & $\begin{array}{l}\text { Eastern } \\
\text { Indonesia }\end{array}$ & Women are the main mushroom collectors. Men and women have a comparable TMK. \\
\hline 41 & Burkina Faso & Women are the main mushroom collectors and vendors. Women have a more profound TMK than men. \\
\hline 42 & Guyana & $\begin{array}{l}\text { Women are the main mushroom collectors engaging in premeditated mushrooming; meanwhile men are only 'opportunistic' } \\
\text { collectors during hunting trips. Women have a more profound TMK than men. }\end{array}$ \\
\hline 43 & Bahrain & $\begin{array}{l}\text { Women are the main mushroom collectors and vendors. They play an almost exclusive role in developing the techniques for } \\
\text { the consumption or storage of useful mushrooms. Mushrooms allow women to gain money, become economically } \\
\text { independent, acquire essentials goods, and complement their diet. }\end{array}$ \\
\hline 44 & Toluca, Mex & $\begin{array}{l}\text { Women are the main mushroom collectors and vendors. Women often manage the income resulting from mushroom sale. } \\
\text { Mothers teach children to distinguish the mushrooms in "good ones" and "bad ones". }\end{array}$ \\
\hline 45 & Nigeria & Women are the main mushroom collectors. \\
\hline 46 & $\begin{array}{l}\text { Upper-Shaba, } \\
\text { Zaire }\end{array}$ & Women are the main mushroom collectors. \\
\hline 47 & Chiapas, Mex & $\begin{array}{l}\text { Women are the main mushroom collectors. Men and women have a comparable TMK. Mothers teach children to distinguish } \\
\text { the good and the bad mushrooms. }\end{array}$ \\
\hline 48 & Australia & Women are the main mushroom collectors. \\
\hline 49 & Nexapa, Mex & Women are the main mushroom collectors. \\
\hline 50 & Colombia & Women are the main mushroom collectors. \\
\hline 51 & Eastern Europe & Women are the main mushroom collectors and vendors. \\
\hline 52 & Geneva, Italy & Collecting is an exclusive masculine activity. \\
\hline 53 & Chiapas, Mex & Men collect in forests while women collect those mushrooms closest to their houses. \\
\hline 54 & Chihuahua, Mex & $\begin{array}{l}\text { Men and women have a comparable TMK. Women play an almost exclusive role in developing the techniques for the } \\
\text { consumption or storage of useful mushrooms. }\end{array}$ \\
\hline 55 & $\begin{array}{l}\text { Boyaca, } \\
\text { Colombia }\end{array}$ & Men and women have a comparable TMK. \\
\hline 58 & Benin & Men are more knowledgeable than women. \\
\hline 59 & Tlaxcala, Mex & $\begin{array}{l}\text { Women's mushrooming routes are more energy-efficient, allowing them to gather the same amount and a greater variety of } \\
\text { wild mushrooms in smaller and more accessible areas of the forest. Most mushroom vendors in markets are women. }\end{array}$ \\
\hline 60 & Tlaxcala, Mex & Most mushroom vendors in markets are women. Mothers encourage children to foray for mushrooms. \\
\hline 61 & Hidalgo, Mex & Men target some of the most desirable species. \\
\hline 62 & Anatolia, Turkey & Women tend to collect in groups reinforcing social networks, in contrast to men who are solitary collectors. \\
\hline 63 & Oaxaca, Mex & Descriptions of rituals indicate that the collectors usually are young virgin women or shamans of indistinct gender. \\
\hline 64 & Puebla, Mex & $\begin{array}{l}\text { Women play an almost exclusive role in developing and refining the techniques for the consumption or storage of useful } \\
\text { mushrooms. }\end{array}$ \\
\hline 65 & Mex tropics & Men guide customers to foraging for hallucinogenic species. \\
\hline 69 & Hidalgo, Mex & Most mushroom vendors in markets are women. \\
\hline $\begin{array}{l}70, \\
72\end{array}$ & $\begin{array}{l}\text { Sierra } \\
\text { Nevada, Mex }\end{array}$ & $\begin{array}{l}\text { Most mushroom vendors in markets are women. Mushrooms are more important for poor women's subsistence than for } \\
\text { men's. }\end{array}$ \\
\hline 71 & Poland & Mushrooms are more important for poor women's subsistence than for men's. \\
\hline 73 & Oaxaca, Mex & Most mushroom vendors in markets are women. \\
\hline
\end{tabular}


Table 1 Ethnomycological studies with gendered data (Continued)

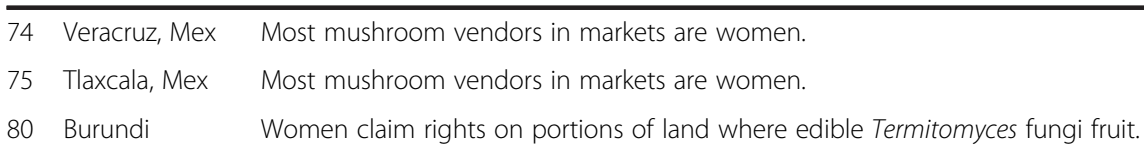

Ref: Reference; TMK: traditional mycological knowledge; Mex: Mexico.

contrasting emotions toward mushrooms ranging from an intense liking to an extreme aversion. We are not aware of any mayor botanical or animal resource producing a comparable phenomenon.

People perceive the kingdoms Animalia and Plantae almost in their entirety, whereas mushrooms are just a small fraction of the Fungi kingdom [5]. As a result, plants and animals are traditionally subdivided into life forms [21] while mushrooms are perceived as a whole $[7,17]$. At most, in some tropical regions they are divided in those growing on wood and those growing from the soil $[22,23]$. Thus, attitudes toward mushrooms are generalized, while animal or plant life forms may produce differential feelings within a society.

There are between 53,000 and 110,000 estimated mushroom species [24], of which around 2800 are used [25].

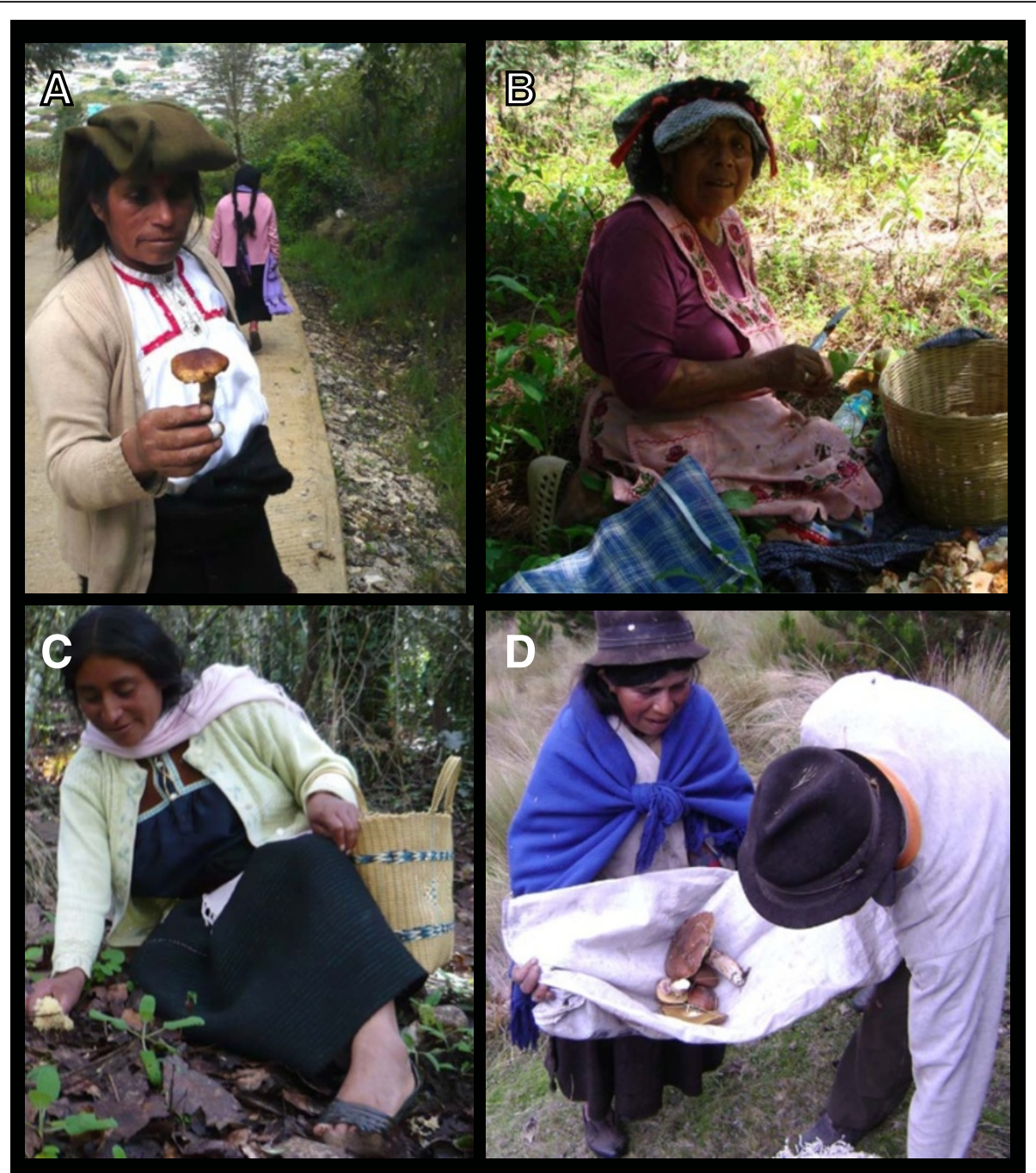

Figure 1 Women collecting mushrooms and bringing them back for self-consumption or sale. 1A - Tsotsil woman with a tricholomatoid fungi coming back to San Juan Chamula, after collecting mushrooms; Photo by Marisa Ordaz-Velázquez. 1B - Nahua woman cleaning collected fungi; Photo by Amaranta Ramírez-Terrazo. 1C - Tsotsil woman collecting Ramaria sp. from a subtropical Quercus spp. forest in San Juan Chamula, Chiapas, Mexico; Photo by Marisa Ordaz-Velázquez. 1D - Kichwa descendants collecting boletes from an open high altitude pine forest in Tungurahua province, Ecuador; Photo by J. Paul Gamboa-Trujillo. 
Because both ethnobotanical and ethnozoological knowledge refer to bigger cultural universes, typically nobody possesses all the information but rather there are specialists (herbalists, shamans, hunters). Mushrooms collectors around the world tend to have a wider knowledge about mushrooms not specializing in particular uses or life forms. An exception would be mazatec shamans who collect Psilocybe spp. for rituals [26]. In some places mushroom collectors gain social recognition. In Hungary, people who know the most about mushrooms are called "the king of mushrooms" [27], in Central Mexico are called "honguero" (mushroomer). They are usually people who became interested in wild mushrooms from a very young age and have accumulated practical and profound knowledge through the years "When I was only ten my mom taught me, and [now] my grandchildren know how to gather mushrooms as well... [I taught] two of my children and four of my grandchildren". We have observed that several elderly women (up to 80 years old) keep collecting mushrooms until they are physically unable to (Figure 1B). During the forum, mushroom gatherers also stated "I am proud to be a mushroom gatherer, I am not ashamed to be", "[we have to] teach our children they must not be ashamed of their parents if they are mushroom gatherers. In my house, my boy is 12 but he does like it; that is the way we are... we were born that way and we will die the same, we are mushroom gatherers". In the United States, where mushroom collection does not have an ethnic or traditional context, the term mushroomer is applied to hobbyists who learn about mushrooms in mycological associations [28] or commercial harvesters, many of them migrants [29].

\section{Women care about use and management of wild mushrooms}

According to the Declaration of the World Summit on Food Security, countries' policies should focus on smallholders and rural women [30]. They are among the poorest in their societies, having limited access to land and paid labor [31]. Their contributions to food security are underestimated because household and subsistence activities are not taken into account in censuses [32]. According to FAO's Forestry Department "Forests and trees on farms are a direct source of food and cash income for more than a billion of the world's poorest people; they provide both staple foods and supplemental foods" [33]. Mushrooms are among the most important wild resources and, as such, they are strategic to FAO's program on the promotion and development of nonwood forest products [25].

Wild mushroom usage involves women in every stage, from collection to processing and selling. There is no gender-specificity requirement to become a local expert. Mushroom gathering may be undertaken by either sex
[34-37], while in Poland men are slightly more involved in it [38]. However in Bahrain, Mexico, Guatemala, Guyana, Nigeria, Zaire, Southeast Asia, Australia, Russia, etc., it is mainly done by women [34,39-51] (Figure 1C, 1D). To our knowledge, the only place where mushroom collecting is an exclusive masculine activity is Geneva [52]. In some tropical regions, men collect in forests while women collect those mushrooms closest to their houses $[16,23,36,53]$. However, in places like Guyana women could be considered the 'champions' of mushroom picking because they engage in active premeditated mushrooming. Meanwhile men are only 'opportunistic' collectors, picking up a few of the more desirable species when encountered on hunting trips [42]. It seems that in many regions of the world women are often the main collectors. This is also the case for plant gathering and managing; women have been recognized as custodians of agrobiodiversity over much of the world [3].

The distribution of local mycological knowledge is variable; those who engage actively in gathering develop a more profound knowledge on the biology, ecology, and phenology of mushrooms and are able to identify them, even at a species level $[27,41]$. Some studies show that men and women have a comparable knowledge $[40,47,54,55]$. On the other hand, certain reports indicate that women have a more profound knowledge $[41,42,56]$ while others have found that men could be more knowledgeable than women $[57,58]$. Female collectors regard gathering as being an enjoyable activity: "I like to eat them, I like to pick them... they are very tasty", "My son is 12 years old and he really likes to go out for mushrooms". Even while they recognize its value as a source of additional income, they would continue to do it without necessity: “. . . if I won the lottery I would still take my family to the woods and we would make a day of it. Just for fun".

Little attention has been paid to the mushroom foraging process. Route tracking studies [59] suggest that mushroom collecting is different for men and women. Women's routes are more energy-efficient, allowing them to gather the same amount and a greater variety of wild mushrooms in smaller and more accessible areas of the forest $[59,60]$. Men, on the other hand, tend to target some of the most desirable species $[42,61]$. Women also tend to collect in groups reinforcing social networks, in contrast to men who are solitary collectors [62].

Collection of mushrooms for ritual use has specific requirements varying between ethnic groups. Descriptions of rituals indicate that the collectors usually are young virgin women or shamans of indistinct gender [63]. Mazatec healers "curanderos" using Psilocybe spp. for curative or divinatory purposes can be either men or 


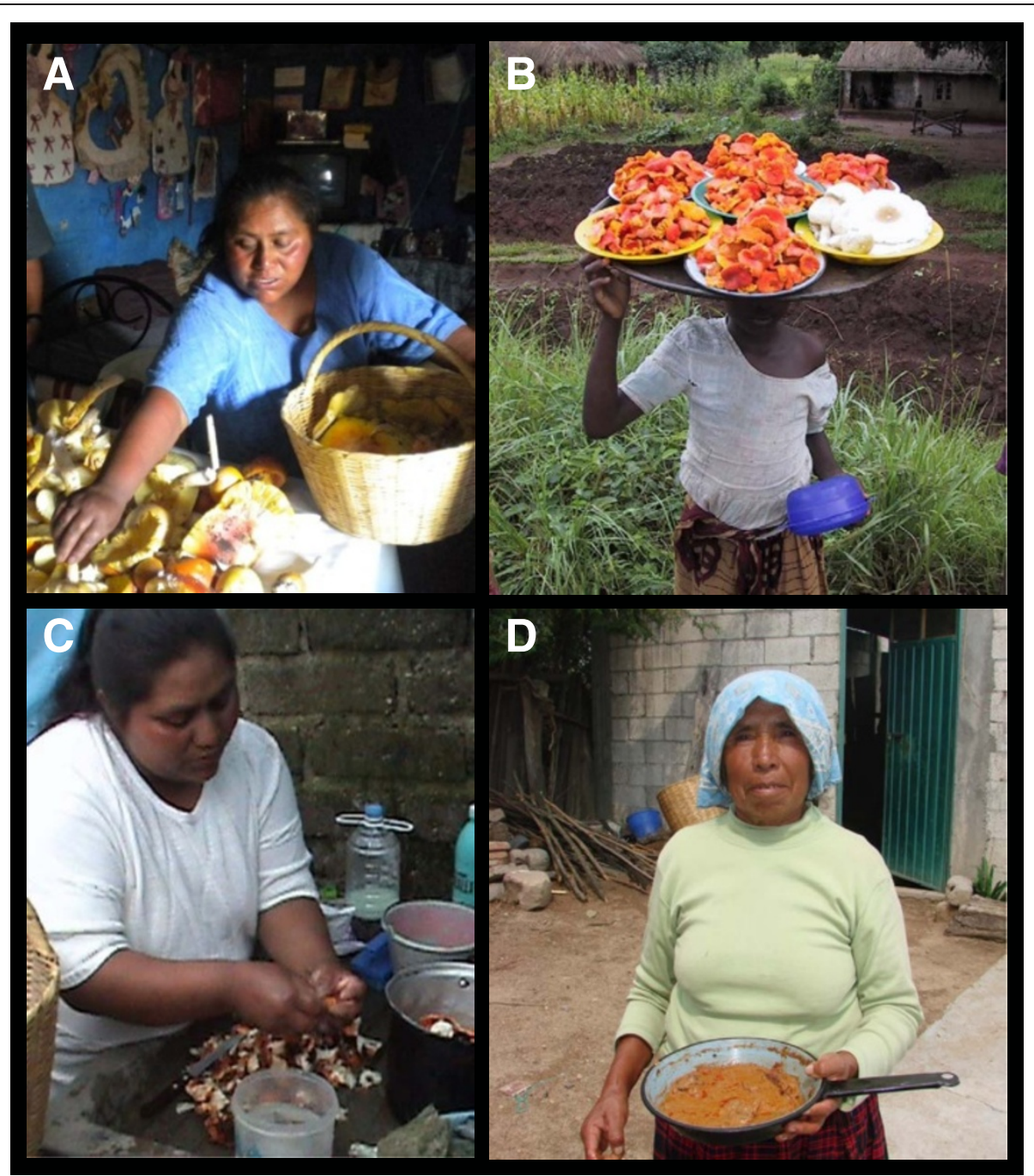

Figure 2 Use and management of wild mushrooms by women. 2A - Women selecting wild mushrooms at home; Photo by Luis Villaseñor Ibarra. 2B - Girl carrying cantharelloid and agaricoid fungi in a bowa in her head after collecting them in the Malawi Miombo woodland; Photo by Eric Boa. 2C - Woman preparing wild mushrooms for cooking; Photo by Luis Villaseñor Ibarra. 2D - Woman with traditional stew "pipian de tlapitzal" made with Gomphus floccosus; Photo by Amaranta Ramírez-Terrazo.

women. Maria Sabina was one of the wisest healers of her time and the key informant of the first ethnomycological studies $[20,26]$.

Women play an almost exclusive role in developing and refining the techniques for the consumption or storage of useful mushrooms [43,54,64] (Figure 2A, 2B). This includes the culinary aspects of wild edible species, a "feminine" space throughout cultures [65] (Figure 2C, 2D). Culinary traditions are a part of cultural identity and can play a role in biodiversity conservation, since they are based on locally available biological resources. Management practices in the kitchen can also make available resources that would otherwise remain unused [3]. Mushrooms of genera including Gyromitra and Gomphus, which are slightly toxic, are boiled and rinsed two or more times before eating $[66,67]$.
Either by sale or self-consumption, mushrooms aid the family's economy during the rainy season. Developing methods for preserving the mushrooms allows this additional income to stretch into the dry season. Another aspect of the economical significance of processing is that it adds value to mushrooms as a marketable product [14]. Mushroom sale occurs at international, national, regional, and local levels [34]. Women can be main players in international or national markets $[11,13]$ beyond being collectors. Regionally women may participate as middlemen selling mushrooms to companies $[11,65,68]$. Selling forest products, such as mushrooms is often an economic alternative for vulnerable groups, such as widows with young children, single moms, or women who are the head of their families [34,36,69]. In various places in Mexico, Africa, and Southeast Asia, 
many families depend on the income obtained from mushroom gathering $[11,25,36,49]$. Only two works $[70,71]$ have studied the relationship between the socioeconomic basis of gender inequality and mushroom use. Both concluded that in places as rural Poland and Mexico where poverty is particularly severe among women, their subsistence partly relies on mushroom sale. However, their contribution to subsistence does not necessarily relate to their status in society [3].

While rural gatherers usually have a modest income, middlemen in urban settings sell a considerable volume of mushrooms per season [14,34]. Locally, commercial activities concerning edible mushrooms may involve both genders. Although in temperate Mexico [34,44,59,60,64,69,72-75], Burkina Faso [41], and Hungary
[27] most of the vendors in markets are women (Figure 3A, 3B). Even though men could accompany them, women establish prices and bargain with customers. In premodern Europe, particularly in east Europe, "marketwomen" were the main suppliers of vegetables and wild mushrooms. Nowadays, this activity continues in the Czech Republic, Ljubljana, Lithuania, Latvia, Romania, Bulgary, Poland, Ukraine, Moscow, St Petesburg, and far east, Russia [51]. In temperate regions of Mexico there is a market for hallucinogenic species used for recreational purposes. In Mexican tropical regions, where wild mushroom sale in markets is marginal [65], men are in charge of taking customers foraging for hallucinogenic species. In some places, even ceremonies for tourists are led by shamans of either sex [76].

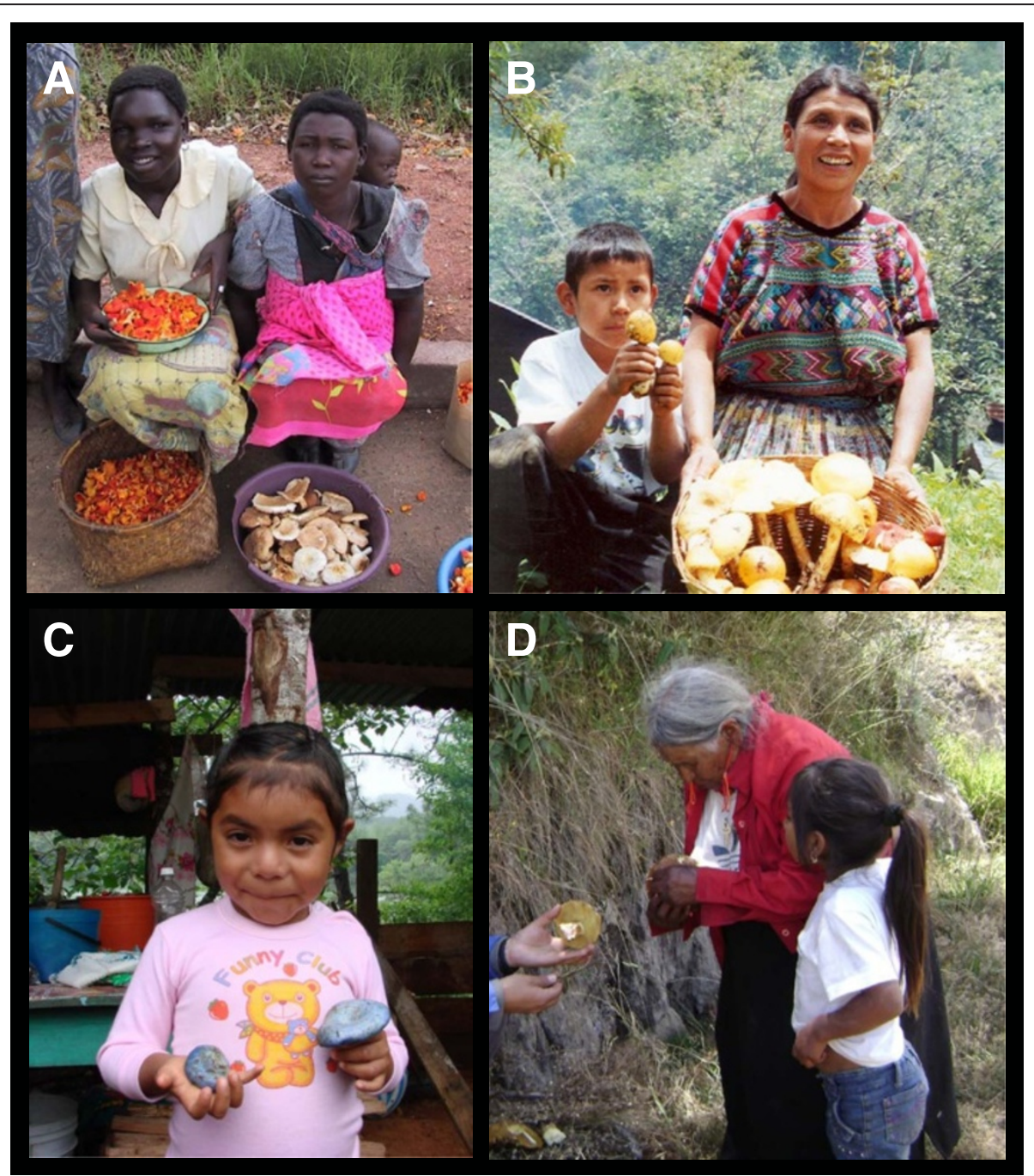

Figure 3 Women and children selling mushrooms and sharing traditional mycological knowledge. 3A- Ladies selling chanterelles and agarics on the road on Malawi; Photo by Eric Boa. 3B - A maya Kaqchikel woman and her son selling Amanita caesarea complex in the town of Xetonox, Chimaltenango, Guatemala; Photo by Roberto Cáceres. 3C - A Tojolabal descendant girl learning about edible mushrooms with some Lactarius indigo in her hands; Photo by Amaranta Ramírez-Terrazo. 3D - One of the oldest informants and a little girl talking about mushrooms with the interviewer in Tungurahua, Ecuador; Photo by J. Paul Gamboa-Trujillo. 
Traditional practices are conserved in local markets where women usually barter the mushrooms that they do not sell during the day for other products. "I carried my basket filled with mushrooms and people traded tortillas, maize, water, squash, chilacayote (Cucurbita ficifolia) for them. Even butchers would offer us meat". By engaging in trading, women make the most of the energy spent in collecting and optimize their income, while the remaining mushrooms are used as food [69]. Barter also has a remarkable social function as a means of constructing and strengthening social bonds [65,73]. Women often manage the income resulting from mushroom sale [44]. They care about using the revenues effectively "We save the money we make for the season when school starts... when they need something we dig into those savings". Thus, mushrooms are a natural resource that allows women to gain some money, become economically independent, acquire essentials goods, and complement their diet $[36,43]$.

Markets provide a space in which local knowledge is shared and transmitted [11,44]. Mushroom vendors coax potential buyers into getting the different varieties they offer by sharing recipes, telling stories, and indicating the proper procedures to ensure safe consumption. Thus, women as vendors permit urban residents to reincorporate wild mushrooms as a dietary choice.

\section{Women's role in traditional knowledge dynamics}

Local knowledge is intrinsically dynamic. It is constructed from a base of inherited knowledge modified by processes of enrichment (innovation, experimentation), loss (transculturation, acculturation), and transformation (syncretism) [77,78].

Rural women are particularly vulnerable in the face of global phenomena such as national policies, economical and ecological crises, food shortage, migration, urbanization, marginalization, transculturation, acculturation, environmental transformation, deforestation, and pollution [79]. Local knowledge serves them as an instrument to deal with these situations. Because local practices are developed through a continuous interaction with the environment, they also tend to be the least destructive means of appropriation. National and international conservation programs currently integrate local knowledge as a strategy to both preserve the environment and promote local identities.

When women are the primary collectors or sellers of mushrooms, they also become the main teachers of local mycological knowledge. In Poland, sex differences in knowledge transmission are slight, although fathers are most mentioned as the first teachers, and boys learn at a younger age than girls [38]. During the first years in which children learn about mushrooms, mothers often encourage them to foray for them $[36,60]$. When the children bring the mushrooms home they help by sorting out the "good ones" from the "bad ones" [34,44,47] (Figure 3C). In women's words: "When I started with this mushroom thing I learned from my mom. She would tell me $<<$ let us go searching for mushrooms $>>$. That is how we grew up", "We have to teach the children from a young age; I take one of my sons, but one of the older girls does not like it. The little one does, and she is learning about mushrooms, later she will like them too". They can also teach people from their own generation "One of my husband's sisters did not gather or look for mushrooms. After she got together with my brother-in-law, I would tell her to join me when I went looking for mushrooms but she would say $<<\mathrm{I}$ do not know them $>>$, so I said to her $<<$ Come on! I will teach you $>>$ and so, she started to learn".

However women are not always the instructors; when they marry into a family in which there is mycological knowledge, they learn from their mothers-in-law, husbands, and even their children "And now my sons [...] are all married... their wives do not want to, but then they go get mushrooms themselves. They bring their children along and teach them the names of the mushrooms they find. Then the wives understand and cook them... their kids explain how. Their wives know now how to prepare mushrooms".

Women are open to other sources of knowledge exchange such as workshops, forums, mushrooms fairs, technical seminars, and training courses. Attendants to the Mushroom Gatherers Forum said so "I took interest in the event because... we were going to talk about mushrooms, share our doubts and problems when we collect mushrooms"; "We decided to come and listen to what other collectors have to say because there are mushrooms we name one way and they name them differently. I was interested in knowing different mushrooms, listening to comments from all the collectors who are different, some coincide with us and some do not".

Women not only transmit their inherited knowledge, they also generate new knowledge by experimentation and appropriation. In Mexico, there is evidence that women have experimented with the consumption of species not previously recognized as edible in their communities. This is accomplished through an intense observation of the biology and ecology of the suspected edible species. When these species share characteristics with other edible species, they are gathered, cooked, and served to a dog several times. If the dog survives, they taste it themselves in small quantities. When they are sure the mushroom is harmless, they serve it to their families. Also, we have observed in Tlaxcala, Mexico, the novel use of Lyophyllum sp. as a cosmetic product through another experimentation process. While soaking 
this edible mushroom, women discovered it softened their skin.

Dugan [51] has documented one of the most interesting chapters in mycology history. He states that Carolus Clusius and Franciscus van Sterbeeck, two pioneers of mycology in the sixteen and seventeen centuries, commonly obtained information about mushrooms from the wise women known as "herbwives". This knowledge transfer happened in a time when many women were prosecuted as witches and killed because their "illicit" botanical knowledge. Strikingly, women's knowledge of fungi did not acquire the status of "science" until collected, systematized, and transmitted by men [51].

\section{Challenges women face during the mushroom appropriation process}

Although mushrooms are considered a free access resource in temperate regions [22], collectors are currently being limited in their access to the forests or are required to pay a fee. "In the state of Puebla, lately they will not let us [gather]... they say we need a permit and that there is a fee. Each time we go we will have to pay... but sometimes we do not sell much. They have not told us how much it will be". In some places of Burundi, women claim rights on portions of land where edible Termitomyces fungi fruit [80]. Women's access to resources and land tenure should be explicitly recognized given their main role in agricultural and forestry practices [3]. Indiscriminate logging has destroyed forests making it more expensive to obtain mushrooms. "We pay the bus fee to get there because it is too far. It would take three or four hours if we walked. If the bus takes us there we can browse the woods all day and we get back home in the afternoon".

In several regions a decrease in wild mushroom production has been documented. In Europe acid rain and forest soil nitrification have modified mushroom communities leading to local extinctions of several species like Cantharellus cibarius [81]. In Japan nematode plagues have destroyed populations of Tricholoma matsutake, one of the most valued edible mushrooms [82]. Local mushroom decrease is a problem collectors face "It has been about six years that you burn but there is no yield... there are no mushrooms there anymore. Very little [grows], there is not as much as before. Our grandparents used to tell how the mushrooms grew close to the houses and they found so much they did not gather it all". They attribute this to logging, damage by livestock, change in rain patterns, and competition. "In our State [Puebla] mushrooms do not grow anymore because of logging... it does not grow nearby anymore. We have to go all the way up to Paso de Cortés [at least
$15 \mathrm{~km}$ from town]", "since cows graze there, the grass is smaller and, well, it does not [grow]. They stamp on it".

There are dangers that are inherent to gathering activities in the forest. While gatherers recognize these, they are not an impediment to them. "In our community, many people have livestock... they do not let us look for mushrooms anymore... there are many [animals] like bulls that can gore us. They tell us they are afraid something might happen... some one has already died and they do not want that to happen again so they will not let us gather mushrooms", "There are many snakes and scorpions, since its weedy we sometimes can not see. You are in the mountain and if the bus does not go by... venom runs fast". Mushroom collectors, as independent workers, face these dangers without social health benefits.

They have few solutions for these trials. Nonetheless, they persist in mushroom gathering because they value this activity as a source of income and as part of their cultural identity (Figure 3D). The most important tools they have to face these challenges are their local knowledge and their skills. These allow them to adapt to changing environmental and social conditions.

\section{Conclusions}

The unique nature of local mycological knowledge distinguishes it from both ethnobotanical and ethnozoological knowledge. This knowledge is based upon fungal biology, ecology, and metabolism, and impacts both management and perception. In rural areas, women are usually unemployed, dedicating themselves to household and subsistence activities. Mushrooms provide a source of income and nourishment, contributing to the food security of this vulnerable group. The literature indicates that, in many regions of the world, they are the principal mushroom collectors. They also play a central role on mushroom processing both for self-consumption and sale. Women are owners of a vast knowledge on mushroom taxonomy, biology, and ecology. They combine this information with their own cultural background as well as external knowledge to improve their subsistence. By doing so, they not only possess local mycological knowledge but also actively influence its evolution and transmission. Mushroom harvesting is a challenging activity that requires a deep local environmental knowledge to achieve success. Women collectors are usually not organized because they are seldom landowners and their activity is seasonal. Thus, they are unable to face challenges such as the loss of forest cover or socio-political restrictions. Women mushroom collectors are conscious of their knowledge, value its 
contribution in their subsistence systems and economy, and are proud of it as part of their cultural identity.

Ethnomycological studies have not been designed specifically to compare gendered knowledge and use of mushrooms. Given that women are a main force in food production and alimentary security, we strongly recommend that future studies take gender perspective into account. Design should include a stratified sampling, allowing gender comparisons. This would reveal gendered knowledge in mushroom management and permit better interpretations.

\section{Additional file}

Additional file 1: Original quotes in Spanish from participants at the National Mushroomer Forum, Mexico 2010. Quotes appear in the order in which they are included in this review.

\section{Competing interests}

Authors declare no competing interests.

\section{Authors' contributions}

RG-O designed the study, coordinated the analysis and interpretation of data, and wrote the manuscript. AR-T and MO-V participated in the design of the study, and made substantial contributions to the interpretation of data and manuscript writing. MO- $\mathrm{V}$ also reviewed the English version. All authors read and approved the final manuscript.

\section{Authors' information}

$\mathrm{RG}-\mathrm{O}$ is an associate researcher at Universidad Nacional Autonoma de Mexico and has done work on the traditional mycological knowledge and mushroom use and management for the last ten years.

AR-T is a graduate student at Universidad Nacional Autonoma de Mexico. She is conducting a research on the cultural significance of non-edible fungi comparing two communities. She is interested in studying the role of fungi in the communities' traditional knowledge.

$\mathrm{MO}-\mathrm{V}$ is an undergraduate Biology student at Universidad Nacional

Autonoma de Mexico working on local traditional knowledge of tsotsil Maya of the Highlands of Chiapas.

RG-O, MO-V, and AR-T are members of Grupo Interdisciplinario para el Desarrollo de la Etnomicologia en Mexico (GIDEM).

\section{Acknowledgements}

UNAM- PAPIT (IN218210) provided partial support to RG-O. Authors thank the members of the Grupo Interdisciplinario para el Desarrollo de la Etnomicologia en Mexico (GIDEM) for their discussion and enrichment of this paper. Felipe Ruan made valuable commentaries on the paper and provided us with data for the nature of local mycological knowledge section. We are particularly grateful to Emma Estrada, the main organizer of the "Primer Foro Nacional de Hongueros" held in Chapingo, Mexico in August 2010, as well as the attending mushroom gatherers. We thank Eric Boa, Paul Gamboa Trujillo, Osberth Morales, and Luis Villaseñor for providing some of the photos displayed in the figures. We thank Ángel Moreno and Robert Bye for their comments on the final English version. We are also grateful with the three anonymous referees who considerably improved the quality and scope of this work.

\section{Author details}

${ }^{1}$ Laboratorio de Sistemática, Ecología y Aprovechamiento de Hongos Ectomicorrízicos, Departamento de Botánica, Instituto de Biología, Universidad Nacional Autónoma de México, Circuito Exterior s/n, A.P. 70-233,

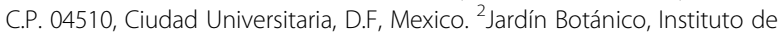
Biología, Universidad Nacional Autónoma de México, A.P. 70-614, C.P. 04510, Ciudad Universitaria, D.F, Mexico. ${ }^{3}$ Facultad de Ciencias, Universidad Nacional
Autónoma de México, A.P. 70-181, C.P. 04510, Ciudad Universitaria, D.F, Mexico.

Received: 23 January 2012 Accepted: 6 July 2012

Published: 18 July 2012

\section{References}

1. Pfeiffer J, Butz R: Assessing cultural and ecological variation in ethnobiological research: the importance of gender. Journal of Ethnobiology 2005, 25:240-278.

2. Davis D, Nadel-Klein J: Gender, culture and the sea: contemporary theoretical approaches, In Women Working in the Environment. Washington, D.C: Sachs CE; 1997:49-63.

3. Howard PL: Women and the plant world: an exploration, In Women and plants, gender relations in biodiversity management and conservation. New York: Zed Books: Howard PL; 2003:1-48.

4. Moreno-Fuentes A, Garibay-Orijel R, Tovar-Velasco J, Cifuentes J: Situación actual de la etnomicología en México y el mundo. Etnobiología 2001, $1: 75-84$.

5. Alexopoulos CJ, Mims CW, Blackwell M: Introductory mycology. 4th edition. New York: Wiley; 1996.

6. Isikhuemen OS, Okhuoya JA: Cultivation of Pleurotus tuber-regium (Fr.) Singer for production of edible sclerotia on agricultural wastes, In Mushroom Biology and Mushroom Products. Pennsylvania: Penn State University: Royse DJ; 1996:429-436.

7. Garibay-Orijel R, Caballero J, Estrada-Torres A, Cifuentes J: Understanding cultural significance, the edible mushrooms case. Journal of Ethnobiology and Ethnomedicine 2007, 3:4.

8. Pieroni A: Evaluation of the cultural significance of wild food botanicals traditionally consumed in Northwestern Tuscany, Italy. Journal of Ethnobiology 2001, 21:89-104.

9. De Roman M, Boa E: The marketing of Lactarius deliciosus in northern Spain. Economic Botany 2006, 60:284-290.

10. Pacheco-Cobos L, Rosetti M, Hudson R: A new method for tracking pathways of humans searching for wild, edible fungi. Micologia Aplicada International 2009, 21:77-87.

11. Arora D: The houses that matsutake built. Economic Botany 2008 62:278-290.

12. Michelot D, Melendez-Howell LM: Amanita muscaria: chemistry, biology, toxicology, and ethnomycology. Mycological Research 2003, 107:131-146.

13. Samils N, Olivera A, Danell E, Alexander SJ, Fischer C, Colinas C: The socieoeconomic impact of truffle cultivation in rural Spain. Economic Botany 2008, 62:331-340.

14. Martínez-Carrera D, Nava D, Sobal M, Bonilla M, Mayett Y: Marketing channels for wild and cultivated edible mushrooms in developing countries: the case of Mexico. Micología Aplicada International 2005, 17:9-20.

15. Deacon JW: Fungal biology, 4th edn. Blackwell Pub: Malden; 2006.

16. Alvarado-Rodríguez R: Aproximacion a la etnomicología zoque en la localidad de Rayón, Chiapas. UNICACH, Escuela de Biología: México; 2006.

17. Lampmann AM: General principles of ethnomycological clasification amonbg tseltales in Tenejapa, Chiapas. Journal of Ethnobiology 2007, 27:11-27.

18. Fericgla JM: El hongo y la génesis de las culturas. Barcelona: Los Libros de la Liebre de Marzo: Duendes y gnomos: Ambitos culturales forjados por el consumno de la seta enteógena Amanita muscaria; 1994.

19. Wasson R, Kramrisch S, Ott J, Ruck C: La Búsqueda de Perséfone: Los enteógenos y los orígenes de la religión. México: Fondo de Cultura Económica; 1992.

20. Wasson V, Wasson R: Mushrooms, Rusia and History. New York: Pantheon Books; 1957.

21. Berlin B: Ethnobiological classification: Principles of categorization of plants and animals in traditional societies. Princeton: Princeton University Press; 1992.

22. Ruan-Soto F, Cifuentes J, Mariaca R, Limón F: Pérez-Ramírez L, Sierra S Uso y manejo de hongos silvestres en dos comunidades de la Selva Lacandona, Chiapas, México. Revista Mexicana de Micologia 2009, 29:61-72.

23. Ruan-Soto F, Garibay-Orijel R, Cifuentes J: Process and dynamics of traditional selling wild edible mushrooms in tropical Mexico. Journal of Ethnobiology and Ethnomedicine 2006, 2:3. 
24. Mueller GM, Schmit JP, Leacock PR, Buyck B, Cifuentes J, Desjardin DE, Halling RE, Hjorstam K, Iturriaga T, Larsson KH: Global diversity and distribution of macrofungi. Biodiversity and conservation 2007, 16:37-48.

25. Boa E: Wild edible fungi a global overview of their use and importance to people. Rome: FAO; 2005.

26. Wasson R: Seeking the magic mushroom. Life 1957, 42:100-120.

27. Győző $Z$ : The meanings and functions of mushrooms as food in hungarian folk tradition. Acta ethnographica hungarica 2010, 55:115-138.

28. Fine GA: Morel tales: The culture of mushrooming. Cambridge: Harvard University Press; 1998.

29. Arora D: Migrant mushroomers: tales of adventure, nature love, and money on the globalocal mushroom trail. Spring: Whole Earth; 2000.

30. FAO: Declaration of the world summit on food security. Rome: Food and Agriculture Organization of the United Nations; 2009.

31. FAO: The state of food insecurity in the world. Rome: Food and Agriculture Organization of the United Nations; 2011.

32. Gender and food security: Synthesis report of regional documents. Africa, Asia and Pacific, Europe, Near East, Latin America: [http://www.fao.org/docrep/ X0198E/x0198e03.htm - P307_41924].

33. Forests, potential solution in the fight against hunger: [http://www.fao.org/ news/story/en/item/93236/icode/l.

34. Perez-Moreno J, Martinez-Reyes M, Yescas-Perez A, Delgado-Alvarado A, Xoconostle-Cazares B: Wild mushroom markets in central Mexico and a case study at Ozumba. Economic Botany 2008, 62:425-436.

35. Trappe JM, Claridge AW, Arora D, Smit WA: Desert truffles of the African Kalahari: ecology, ethnomycology, and taxonomy. Economic botany 2008, 62:521-529.

36. Van Dijk H, Awana-Onguene N, Kuyper TW: Knowledge and utilization of edible mushrooms by local populations of the rainforest of south Cameroon. Ambio 2003, 32:19-23.

37. Zent EL: Mushrooms for Life among the Jotï in the Venezuelan Guayana. Economic Botany 2008, 62:471-481.

38. Luczaj L, Nieroda Z: Collecting and learning to identify edible fungi in Southeastern Poland: age and gender differences. Ecology of Food and Nutrition 2011, 50:319-336.

39. Arora D: Asia. Economic botany 2008, 62:254-256

40. Ellen R: Ethnomycology among the Nuaulu of the Moluccas: Putting Berlin's "general principles" of ethnobiological classification to the test. Economic Botany 2008, 62:483-496.

41. Guissou KML, Lykke AM, Sankara P, Guinko S: Declining wild mushroom recognition and usage in Burkina Faso. Economic Botany 2008, 62:530-539.

42. Henkel TW, Aime MC, Chin M, Andrew C: Edible mushrooms from Guyana. Mycologist 2004, 18:104-111.

43. Mandeel QA, Al-Laith AA: Ethnomycological aspects of the desert truffle among native Bahraini and non-Bahraini peoples of the Kingdom of Bahrain. Journal of Ethnopharmacology 2006, 110:118-129.

44. Mariaca-Méndez R, Silva-Pérez LC, Castaños-Montes CA: Proceso de recolección y comercialización de hongos comestibles silverstres en el Valle de Toluca, México. Ciencia Ergo Sum 2001, 8:30-40.

45. Okhuoya JA, Akpaja EO, Osemwegie OO, Oghenekaro AO, Ihayere CA: Nigerian mushrooms: underutilized non-wood forest resources. Journal of Applied Sciences and Environmental Management 2010, 14:43-54.

46. Parent G, Thoen D: Food Value of Edible Mushrooms from Upper-Shaba Region I. Economic botany 1977, 31:436-445.

47. Shepard GH, Arora D, Lampman A: The grace of the flood: Classificantion and use of wild mushrooms among the Highland Maya of Chiapas. Economic Botany 2008, 62:437-470.

48. Trappe JM, Claridge AW, Claridge DL, Liddle L: Desert truffles of the australian outback: Ecology, ethnomycology, and taxonomy. Economic Botany 2008, 62:497-506.

49. Valencia-Flores IA: Uso tradicional de los hongos silvestres en San Pedro Nexapa. UNAM, Facultad de Ciencias: Estado de México; 2006.

50. Vasco-Palacios AM: Estudio etnobiológico de los hongos macromicetes entre los Uitoto de la región de Araracuara (Amazonia Colombiana). Facultad de Ciencias: UNAL; 2002

51. Dugan FM: Conspectus of world ethnomycology: Fungi in ceremonies, crafts, diets, medicines, and myths. St. Paul, MN: American Phytopathological Society; 2011.

52. Weber C: The Popularity of Edible Mushrooms in Geneva. Economic botany 1964, 18:254-255.
53. Ramírez-Terrazo A: Estudio etnomicológico comparativo entre dos comunidades aledañas al Parque Nacional Lagunas de Montebello, Chiapas. UNAM, Facultad de Ciencias: México; 2009

54. Moreno-Fuentes A: Estudio etnomicológico comparativo entre comunidades Rarámuris de la Alta Tarahumara en el estado de Chihuahua. Posgrado en Ciencias Biológicas: UNAM; 2002.

55. Pérez-Gordillo EC, Piraguata-Peña ML: Estudio etnomicológico entre los campesinos de los municipios de Arcabuco y Moniquirá. UPTC, Escuela de Ciencias Biológicas: Departamento de Boyacá; 2006.

56. Morris B: The Pragmatics of Folk Classifications. Journal of Ethnobiology 1984, 4:45-60

57. De Kesel A: Codja JTC, Yorou SN: Guide des champignons comestibles du Bénin. Meise: Jardin Botanique National de Belgique and Centre International d'Ecodéveloppement Intégré; 2002.

58. Yorou SN, De Kesel A: Connaissances ethnomycologiques des peuples Nagot du centre du Bénin (Afrique de l'Ouest). Systematics and Geography of Plants 2002, 71:627-637.

59. Pacheco-Cobos L, Rosetti M, Cuatianquiz C, Hudson R: Sex differences in mushroom gathering: men expend more energy to obtain equivalent benefits. Evolution and Human Behavior 2010, 31:289-297.

60. Montoya A, Hernandez N, Mapes C, Kong A, Estrada-Torres A: The collection and sale of wild mushrooms in a community of Tlaxcala, Mexico. Economic Botany 2008, 62:413-424.

61. Moreno-Fuentes A, Bautista-Nava E: El "hongo blanco patón", Pleurotus albidus, en Hidalgo. Su primer registro en México. Revista Mexicana de Micología 2006, 22:41-47

62. Ertuğ F: Gendering the tradition of plant gathering in Central Anatolia (Turkey), In Women and plants: gender relations in biodiversity management and conservation. New York: Zed Books: Howard PL; 2003:183-196.

63. Ravicz R: La mixteca en el estudio comparativo del hongo alucinante. INAH 1961, 13:73-92.

64. Pellicer-González E, Martínez-Carrera D, Sánchez M, Aliphat M, EstradaTorres A: Rural management and marketing of wild edible mushrooms in Mexico. Products WSoMBaM: In International Conference on Mushroom Biology and Mushroom Products; Cuernavaca; 2002:1-14.

65. Ruan-Soto JF, Garibay-Orijel R, Cifuentes J: Conocimiento micológico tradicional en la planicie costera del Golfo de México. Revista Mexicana de Micología 2004, 19:57-70

66. Montoya A, Hernández-Totomoch O, Estrada-Torres A, Kong A, Caballero J: Traditional knowledge about mushrooms in a Nahua community in the state of Tlaxcala, Mexico. Mycologia 2003, 95:793-806.

67. Reygadas-Prado F, Zamora-Martínez M, Cifuentes J: Conocimiento sobre los hongos silvestres comestibles en las comunidades de Ajusco y Topilejo, D.F. Revista Mexicana de Micología 1995, 11:85-108.

68. García-Morales I: Contribución al estudio etnomicológico en el Distrito Federal, delegación Magdalena Contreras. Facultad de Ciencias: UNAM; 2008.

69. Alavez-Vargas M: Conocimiento micológico tradicional en San Miguel el Cerezo, Pachuca, Hidalgo: el caso de Boletaceae sensu Chevalier. Facultad de Ciencias, UNAM: UNAM; 2006

70. Estrada E: Importancia del conocimiento micológico tradicional dentro de un marco socioeconómico en la Sierra Nevada, México.: Revista Mexicana de Ciencias Forestales, in press.

71. Tarkowska E: Intra-household gender inequality: hidden dimensions of poverty among Polish women. Communist and Post-Communist Studies 2002, 35:411-432.

72. Estrada-Martínez E, Guzmán G, Cibrián-Tovar D, Ortega-Paczka R: Contribución al conocimiento etnomicológico de los hongos comestibles silvestres de mercados regionales y comunidades de la sierra nevada (México). Interciencia 2009, 34:25-33.

73. Garibay-Orijel R, Cifuentes J, Estrada-Torres A, Caballero J: People using macro-fungal diversity in Oaxaca, Mexico. Fungal Diversity 2006, 21:41-67.

74. Jarvis MC, Miller AM, Sheahan J, Ploetz K, Ploetz J, Watson RR, Ruiz MP, Villapan CAP, Alvarado JG, Ramirez AL, Orr B: Edible wild mushrooms of the Cofre de Perote region, Veracruz, Mexico: An ethnomycological study of common names and uses. Economic Botany 2004, 58:S111-S115

75. Montoya A, Estrada-Torres A, Kong A, Juárez-Sánchez L: Commercialization of wild edible mushrooms in the Markets of Tlaxcala, Mexico. Micología Aplicada Internacional 2001, 131:31-40.

76. Guzmán G: Hallucinogenic mushrooms in Mexico: An overview. Economic Botany 2008, 62:404-412. 
77. Ohmagari K, Berkes F: Transmission of indigenous knowledge and bush skills among the Western James Bay Cree women of subarctic Canada. Human Ecology 1997, 25:197-222.

78. Ruddle K: The transmission of traditional ecological knowlede. Inglis JT. Ottawa: IPTEK, IDRC: In Traditional ecological knowledge; concepts and cases; 1993:17-32.

79. Sánchez E, Espinosa G: Mujeres indígenas y medio ambiente, Una reflexión desde la región de la mariposa monarca. In Género y medio ambiente. México: Ecosur, Semarnat y Plaza y Valdés: Tuñón E; 2003:129-144.

80. Buyck B: Ubwoba: Les Champignons Comestibles de l'Ouest du Burundi. Bruxelles: AGCD; 1994.

81. Amaranthus MP: The importance and conservation of ectomycorrhizal fungal diversity in forest Ecosystems, Lessons from Europe and the Pacific Northwest. Portland: U.S: Department of Agriculture, Forest Service, Pacific Northwest Research Station; 1998.

82. Saito H, Mitsumata G: Bidding customs and habitat improvement for Matsutake (Tricholoma matsutake) in Japan. Economic Botany 2008, 62:257-268.

doi:10.1186/1746-4269-8-25

Cite this article as: Garibay-Orijel et al:: Women care about local

knowledge, experiences from ethnomycology. Journal of Ethnobiology and Ethnomedicine 2012 8:25.

\section{Submit your next manuscript to BioMed Central and take full advantage of:}

- Convenient online submission

- Thorough peer review

- No space constraints or color figure charges

- Immediate publication on acceptance

- Inclusion in PubMed, CAS, Scopus and Google Scholar

- Research which is freely available for redistribution 